Check for updates

New York

Cite this as: BMJ 2021;375:n2956 http://dx.doi.org/10.1136/bmj.n2956 Published: 30 November 2021

\title{
Covid 19: Omicron is a cause for concern, not panic, says US president
}

\section{Janice Hopkins Tanne}

President Joe Biden told Americans that the newly identified omicron variant of the covid-19 virus was a cause for concern, not panic. Mask wearing and vaccinations for all those eligible would protect people and lockdowns were not planned, he said.

Biden spoke at a White House press conference with his medical advisor, Anthony Fauci, director of the National Institute of Allergy and Infectious Diseases. ${ }^{1}$

No omicron variants have been identified in the US, but it is only a matter of time before cases of the highly transmissible variant appear, Fauci said. The US has restricted travel from several African countries to delay arrival of the variant.

Biden stressed the importance of getting those who are eligible-people over the age of 5-fully vaccinated and getting booster shots to people over 18. "If you are not vaccinated, now is the time to get vaccinated and take your children to be vaccinated," he said. The vaccines are free and available at 80000 locations across the nation. He said his team was working with Pfizer, Moderna, and Johnson and Johnson to develop vaccines or boosters against the new variant if needed.

Biden promised that on 1 December he would announce "a detailed strategy outlining how we're going to fight covid this winter-not with shutdowns or lockdowns but with more widespread vaccinations, boosters, testing, and more."

Centers for Disease Control and Prevention director Rochelle Walensky strengthened recommendations for booster shots because of the emergence of the omicron variant. All adults should get boosters six months after receiving the Pfizer or Moderna vaccines or two months after receiving the Johnson \& Johnson vaccine, she said. ${ }^{2}$

Biden praised South Africa for quickly notifying the world of omicron's emergence. "This kind of transparency is to be encouraged and applauded because it increases our ability to respond quickly to any new threats," he said.

However, the US lags other nations in gene sequencing, the technique that allowed South African scientists to identify omicron. Iceland is the leader in sequencing, according to Johns Hopkins University. It has sequenced $29.2 \%$ of samples, compared with $4.08 \%$ in the UK, 3.5\% in China, $2.34 \%$ in Ireland, $2.33 \%$ in Canada, $0.997 \%$ in the US, and $0.206 \%$ in South Africa. The number of samples varied greatly, from 5090 in Iceland, to 416671 in the UK, 480983 in the US, and 6096 in South Africa. ${ }^{3}$

Genome sequencing enables researchers and public health authorities to identify and characterise emerging variants. Variant surveillance is important to determine if emerging mutations are rendering the virus more contagious, more potent, or resistant to existing vaccines and drugs, according to Jennifer Nuzzo of Johns Hopkins' Center for Health Security. ${ }^{3}$

The World Health Organization warned that the omicron variant is a "very high" risk globally. ${ }^{4}$ Cases have been reported in more than a dozen countries.

Although no cases have yet been identified in the US, New York State governor Kathy Hochul has declared a state of emergency so that the state can acquire needed supplies, increase hospital capacity, tackle potential staffing shortages, and limit non-essential surgeries-particularly in the hard hit northern part of the state. Meanwhile, New York City health commissioner Dave Chokshi urged all New Yorkers to wear masks indoors even if they were fully vaccinated, as did outgoing mayor Bill de Blasio and incoming mayor Eric Adams. ${ }^{5}$

Remarks by President Biden providing an update on the omicron variant. 29 November 2021. www.whitehouse.gov/briefing-room/speeches-remarks/2021/11/29/remarks-by-president-biden-providing-an-update-onthe-omicron-variant.

2 Walensky R. CDC expands covid-19 booster recommendations. Centers for Disease Control and Prevention. 29 November 2021. www.cdc.gov/media/releases/2021/s1129-booster-recommendations.html.

3 Johns Hopkins University corona virus resource center. The search for covid-19 variants. https://coronavirus.jhu.edu/data/variant-data.

$4 \quad$ World Health Organization. Update on omicron. 28 November 2021. www.who.int/news/item/28-11-2021-update-on-omicron.

$5 \quad$ Kimball S. NYC reinstitutes covid mask advisory 'at all times' indoors regardless of vaccination status. CNBC New York. 29 November 2021 www.nbcnewyork.com/news/local/ny-continues-to-monitor-omicron-variant-as-us-travel-ban-goes-into-effect/3422788.

This article is made freely available for use in accordance with BMJ's website terms and conditions for the duration of the covid-19 pandemic or until otherwise determined by BMJ. You may use, download and print the article for any lawful, non-commercial purpose (including text and data mining) provided that all copyright notices and trade marks are retained. 